\title{
ELECTRON MICROSCOPIC CHANGES IN THE CELLULAR AND EXTRACELLULAR STRUCTURES OF THE ADRENAL AND THYROID GLANDS DURING ACUTE HYPOXIA
}

\section{S.M. YAGUBOVA}

Department of Pathological Anatomy, Azerbaijan Medical University, Baku, Azerbaijan

Objective: To study the morphofunctional features of ultrastructural changes in the cellular and extracellular structures of adrenal and thyroid glands during acute hypoxia.

Methods: During the study, thyroid and adrenal glands of adult male white rats with a mass of 180-200 grams divided into 2 groups were used. In the course of the study, anatomic, histological, electron microscopic and morphometric examination methods were implemented.

Results: Thus, in the comparative analysis of electron micrographs obtained from the ultrathin sections of both glands, cellular and extracellular acute dystrophic and destructive changes of adrenocytes of the adrenal gland induced by the acute hypoxia - separation of basal membranes into layers, edema of cells, hypertrophy as a compensatory reaction and vacuolation of organelles - observed at the early stage (second day) of the experiment, and on the 5th day of the experiment in thyrocytes and cytoplasmic organelles of the thyroid gland.

Conclusions: As a result of the study, it can be concluded that hypobaric hypoxia affects the morphofunctional state of the adrenal and thyroid glands as the main "stress» factor, causes cellular and extracellular structural changes in the glands. Because the resistance of the adrenal and thyroid glands to hypoxia, especially strong short-term hypoxic effects, is different, the cells (adrenocytes and thyrosites), vessels and connective tissue structures of the glands respond with varying degrees of damage and changes with different morphofunctional reactions. Dystrophic and destructive changes in the adrenal gland, especially on the ultrastructural level are more pronounced, as the adrenal gland is more and more exposed to the influence of endogenous and exogenous factors compared to the thyroid gland.

Keywords: Electron microscopy, thyroid gland, adrenal gland, acute hypoxia.

For citation: Yagubova SM. Electron microscopic changes in the cellular and extracellular structures of the adrenal and thyroid glands during acute hypoxia. Vestnik Avitsenny [Avicenna Bulletin]. 2019;21(4):590-6. Available from: https://doi.org/10.25005/2074-0581-2019-21-4-590-596.

\section{ЭЯЕКТРОННО-МИКРОСКОПИЧЕСКИЕ ИЗМЕНЕНИЯ В КЯЕТОЧНЫХ И ВНЕКЯЕТОЧНЫХ СТРУКТУРАХ НАДПОЧЕЧНИКОВ И ЩИТОВИДНОЙ ЖЕЯЕЗЫ ПРИ ОСТРОЙ ГИПОКСИИ}

С.М. ЯГУБОВА

Кафедра патологической анатомии, Азербайджанский медицинский университет, Баку, Азербайджан

Цель: изучить морфофункциональные особенности ультраструктурных изменений клеточных и внеклеточных структур надпочечников и щитовидной железы при острой гипоксии.

Материал и методы: в ходе исследования использовались щитовидные железы и надпочечники взрослых самцов белых крыс массой 180 200 г. Применялись анатомические, гистологические, электронно-микроскопические и морфометрические методы исследования.

Результаты: сравнительный анализ электронограмм, полученных из ультратонких срезов надпочечников, показал, что, вследствие острой гипоксии, на вторые сутки эксперимента, происходят острые клеточные и внеклеточные дистрофические и деструктивные изменения - расслоение базальных мембран, отёк клеток, гипертрофия и вакуолизация органелл. Подобные изменения наблюдаются на пятые сутки эксперимента и в тироцитах и цитоплазматических органеллах щитовидной железы.

Заключение: в результате проведённого исследования можно сделать вывод, что гипобарическая гипоксия, как основной «стрессовый» фактор, влияет на морфофункциональное состояние надпочечников и щитовидной железы, вызывает клеточные и внеклеточные структурные изменения в железах. Поскольку устойчивость надпочечников и щитовидной железы к гипоксии, особенно сильным кратковременным гипоксическим воздействиям, различна, то повреждение и различные морфофункциональные реакции клеток (адреноцитов и тироцитов), сосудов и соединительнотканных структур желёз проявляются также по-разному. Дистрофические и деструктивные изменения в надпочечнике, особенно на ультраструктурном уровне, более выражены, так как последний больше подвержен воздействию эндогенных и экзогенных факторов по сравнению с щитовидной железой.

Ключевые слова: электронная микроскопия, щитовидная железа, надпочечники, острая гипоксия.

Для цитирования: Yagubova SM. Electron microscopic changes in the cellular and extracellular structures of the adrenal and thyroid glands during acute hypoxia. Vestnik Avitsenny [Avicenna Bulletin]. 2019;21(4):590-6. Available from: https://doi.org/10.25005/2074-0581-2019-21-4-590-596.

\section{INTRODUCTION}

Hypoxia is a common pathological process caused by impairment of biological oxidation resulting in disruption of the energy supply which is important for functioning and survival of each living organism [1-3]. To provide normal metabolism, mitochondria need to receive constantly the required amount of substrate and oxygen to be able to continuously synthesize sufficient amount of adenosine triphosphate (ATP) [4-6].

If the demand for ATP is not met, metabolic, functional and morphological changes occur in the endocrine glands, along with the organs of the respiratory, nervous and cardiovascular system, 
and at the same time, various compensatory processes develop [7, 8]. Therefore, hypoxia is considered as a pathogenetic basis and an important component of many diseases. On the other hand, recently it was shown that modeling of limited oxygen deficiency may result in development of long-term adaptation against hypoxia, which may help to develop certain schemes for the prevention and correction of various diseases with a hypoxic component in their pathogenesis $[9,10]$.

Hypoxia is a powerful stress activating secretion of glucocorticoids by the hypothalamic-pituitary-adrenal system. Glucocorticoids activate the respiratory enzymes and stabilize the cell membrane, as well as the membrane of lysosomes thus reducing the risk of penetration of their hydrolytic enzymes into the cytoplasm [11-14].

In spite of numerous investigations on adaptation of the body to hypoxia, many aspects of this problem remain unclear, such as the scope and the range of morphofunctional changes in the endocrine glands, particularly the adrenal and thyroid glands, which play an important role in the body adaptation to hypobaric hypoxia [15-17].

The objective of this research is to study the ultrastructural changes in the cellular and extracellular structures of the adrenal and thyroid glands during acute hypoxia.

\section{MATERIAL AND METHODS}

Animal research was carried out in Pharmacology and Experimental Surgery Departments, and the Electron Microscopy Laboratory of the Scientific Research Center of Azerbaijan Medical University. The design of experiment was approved by the Ethical Committee (Protocol No. 31 of the Ethics Rules Commission and Bioethics Committee under the Ministry of Health of the Republic of Azerbaijan on 21.04.2008). Total of 40 normal male white outbred rats weighing 180-200 grams, were used in the study. Experimental animals were kept in standard vivarium conditions with food provided ad libitum. The animals were divided into 2 groups: control and experimental, with 20 animals in each group.

The experimental animals were subdivided into 2 equal subgroups (subgroup 1 and subgroup 2) with duration of experiment for 2 and 5 days accordingly. All experimental animals were kept in a special barochamber, which was ventilated 2 times a day for 2 hours with 1 hour break at 10:00-15:00 hours, which is considered the lightest time of day. Temperature was $19-20^{\circ} \mathrm{C}$, pressure is equal to the pressure at an altitude of 2000-3000 meters above sea level, particles of natron lime $\left(\mathrm{Ca}(\mathrm{OH})_{2} 81 \%+\mathrm{NaOH} 3,4 \%+\mathrm{H}_{2} \mathrm{O} 15,6 \%\right)$ were applied to absorb $\mathrm{CO}_{2}$.

Experiment and control animals were euthanized by decapitation under anaesthesia by injection of $2-2,5 \%$ of thiopentalsodium. Thyroid and adrenal glands were sampled and analyzed using histological, electron microscopic and morphometric methods.

Tissue processing for electron microscopy was done as recommended. Semithin (1-2 $\mu \mathrm{m})$ and ultrathin (70-100 $\mathrm{nm}$ ) sections of the embedded tissue were obtained on the ultratome LGB-III, Leica EM OC7. Semithin sections were stained 0,5\% methylene blue, conterstained with $1 \%$ Azur II, mounted and viewed under light microscope "Olympus BX-41». Ultrathin sections 70-100 $\mathrm{nm}$ thick were stained with $2 \%$ uranium-acetate solution and $0,6 \%$ pure lead-citrate and studied under JEM-1400 transmission electron microscope (JEOL, Japan) with 80-120kV voltage.

Morphometric parameters were analyzed statistically using Statistica 10 (StatSoft Inc., USA) software and the Mann-Whitney U-test was performed.

\section{RESULTS AND DISCUSSION}

During the electron microscopic examination of the adrenal gland of the control animals, the cell membrane of the adrenocytes is clearly monitored, but in some parts, the microplicae of plasmalemma are somewhat thickened. The cell has a light-colored cytoplasm and a round nucleus located in the center of the cell, the nucleolus of which is located in the periphery.

Sometimes, lipid vesicles are not detected in the cells of the reticular zone. The crystae of the elongated mitochondria, are clearly visible. The edges of the crystae are smooth, sometimes dentate. The endoplasmic reticulum is composed of oval, small-sized vesicles, some of them are stretched. The existing tight contacts between mitochondria and lipid vesicles and the endoplasmic reticulum are well noticeable.

The Golgi complex consists of cisterns, vacuoles, and vesicles, located near the nucleus. A small number of lysosomes and ribosomes appear mainly around the Golgi complex (Fig. 1).

There are numerous microvilli on the surface of the thyrocytes facing to the follicle cavity, and finger-shaped protrusions on the lateral surfaces, are clearly distinguished. The penetration of these protrusions into the corresponding impressions of the lateral surface of the neighboring cells reflects a close relationship between the thyrocytes. Transparent cytoplasm of thyrocytes and intracellular organelles, unevenly distributed in the cytoplasm, the contacts between them are well noticeable (Fig. 2).

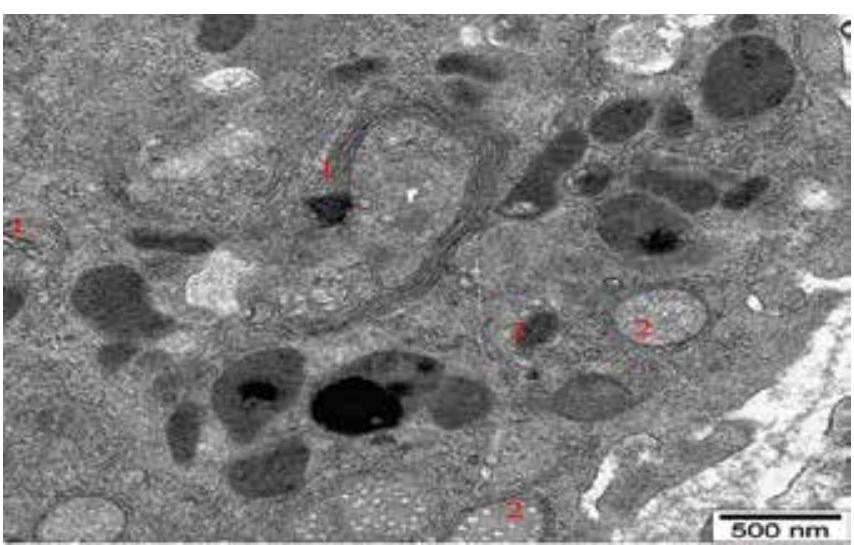

Fig. 1 Electron micrograph of the reticular zone of the adrenal gland of the control animal. TEM. Stain: uranium acetate and pure lead citrate. Scale: 500 nm. 1 - Golgi complex; 2-lysosome; 3-mitochondria

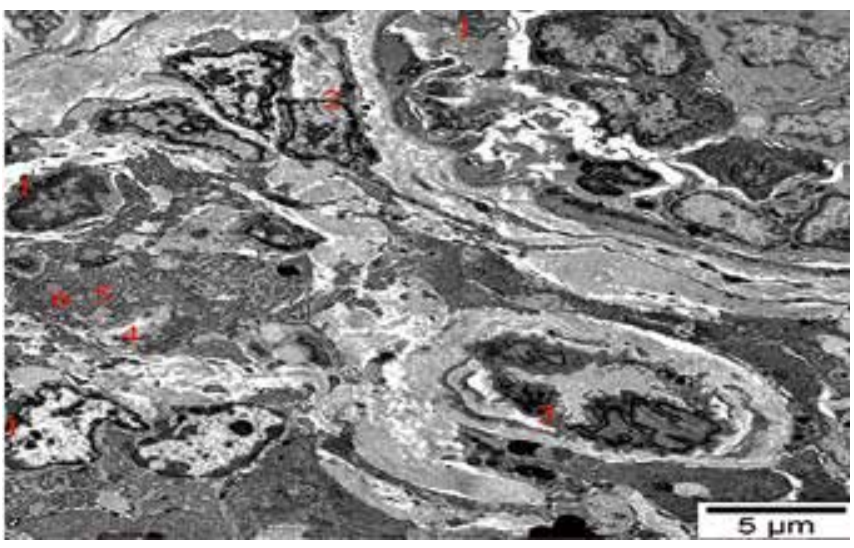

Fig. 2 Electron micrograph of the thyroid gland of the control animal. TEM. Stain: uranium acetate and pure lead citrate. Scale: 5 $\mu m .1$ - thyrocytes; 2 - basal membrane of thyrocyte; 3 - capillary endothelium; 4-Golgi complex; 5 -lysosomes; 6-mitochondria 


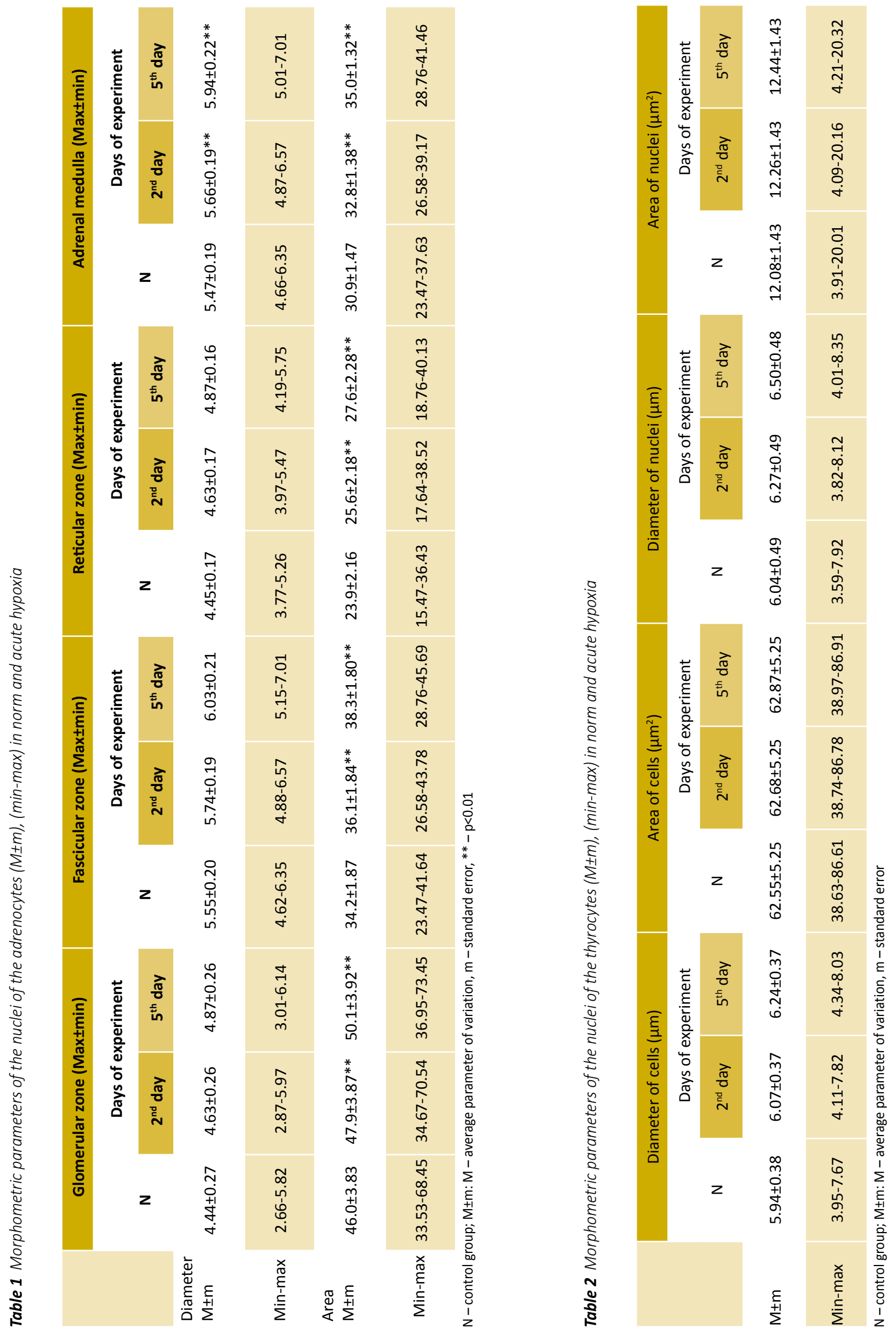


Thus, the nucleus in the center of the cell, the eccentric nucleolus, lipid vesicles dispersed around the nucleus, ribosomes, mitochondria, lysosomes, endoplasmic reticulum, and Golgi complex attract attention with clear contours.

In experimental animals of the $1^{\text {st }}$ subgroups $(2$ days of exposure) the growth of the volume of the adrenal and thyroid glands of animals loosening of the capsule, pale-yellowish color and partial fragility of the consistency are observed.

During the examination of histological preparations, slight dystrophic and destructive changes in the cells of the adrenal and thyroid glands are detected. The morphometric parameters also did not show any significant changes compared to the control group (Tables 1, 2).

On the second day of the experiment, electron micrographs show the loosening of the basal membrane layers in the adrenocytes of the adrenal gland, and in some cells, it is possible to see even a disruption of the integrity of the basal membrane. The cytoplasm of adrenocytes has edema, vesicles, nuclei have blurred and unclear contours, even they are deformed in some cells, a nucleus with two nucleoli is also found. The nucleus and the nucleolus are located mainly on the periphery of the cell - adjacent to the cytolemma. Nuclear chromatin is pale, unevenly distributed, in some cells, especially in the cells of the reticular zone, the destruction of nuclear chromatin is clearly noticeable. Edema, swelling of adrenocytes also causes dystrophic and destructive changes in intracellular organelles (Fig. 3).

From the electron micrographs it appears that the number of lipid vesicles in the cytoplasm has decreased, the contours are not clear. Mitochondria have undergone dystrophic changes, the majority of them are edematous, in particular, the outer membrane has thickened and the crystae have become smooth.

Mitochondria changed their elongated forms and become rounded. In some cells, mitochondria with a bright matrix and normal crystae are also found. Lysosomes and ribosomes are unevenly dispersed in the cytoplasm, the endoplasmic reticulum and the Golgi complex are poorly noticeable. The vesicles of the smooth endoplasmic reticulum are slightly expanded. Marked ultrastructural changes are clearly noticeable, especially in adrenocorticocytes. In the cytoplasm associated with hypoxia, single-fat and small amounts of glycogen grains are determined. This is explained by the fact that as a result of oxygen deficiency, the endothelial cells of adrenocytes use glycogen.

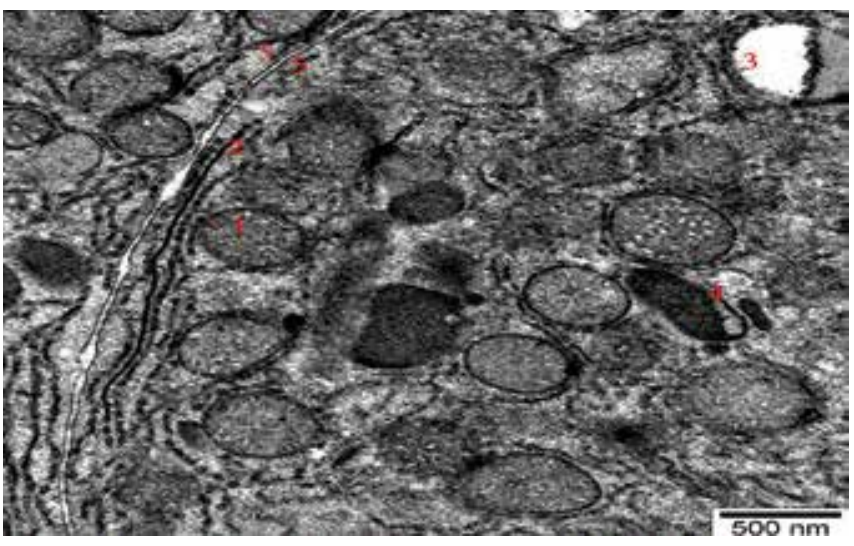

Fig. 3 Electron micrograph of the reticular zone of normal structure of cells of the suprarenal gland. TEM. Stain: uranium acetate and pure lead citrate. Scale: $500 \mathrm{~nm}$. 1 -lysosome; 2 -ribosome; 3 -destroyed lysosome; 4-destroyed mitochondria; 5 -plasmolemma
During the study of ultrathin sections, acute ultrastructural changes in connective tissue and plasmalemma of capillaries are not visible. So, the fenestrae of the endothelial cells of the capillaries surrounding the adrenocytes are clearly visible. Capillaries were plethoric, the lumen was slightly enlarged, the walls were subjected to weak ultrastructural changes.

During the examination of the adrenal gland, the area and diameter of nuclei of adrenocytes in the glomerular, fascicular and reticular zones of the adrenal cortex, as well as in the adrenal medulla, are increased (Table 1).

On the $2^{\text {nd }}$ day of the experiment electron microscopically are detected weak dystrophic changes in the thyroid follicles, as well as in the epithelial cells of thyrocytes on the ultrastructural level. These changes are manifested mainly by an increase in the volume of thyrocytes and hypertrophy of intracellular organelles, especially mitochondria. In electron micrographs, the basal membrane of the thyrocytes is loosened, although the cytoplasm and nucleus are slightly edematous, contours are clearly visible. The protrusions on the lateral surface of the thyrocytes are swollen, the shape of which is relatively changed. The nucleus is located outside the center adjacent to the plasmalemma, and contours are unclear.

Under the influence of hypoxia, intracellular organelles, mainly mitochondria, have weak edema, their crystae have relatively changed shape and are distributed unevenly in the cytoplasm (Fig. 4).

The size of lysosomes, ribosomes, and liposomes is relatively increased, the numbers are reduced, the endoplasmic reticulum is not well noticeable. The cisterns of the Golgi complex are lightly enlarged. Ultrastructural changes in connective tissue and walls of capillaries are not detected. Endothelial cells of capillaries are relatively pale, endothelial cells that have undergone apoptosis locally in some areas, especially in the central part of the gland. On the $2^{\text {nd }}$ day of the experiment, due to a decrease in oxygen supply, an increase in the area and diameter of the thyrocytes is observed. This growth is also recorded in similar indicators.

On the $5^{\text {th }}$ day of the experiment, noticeable acute dystrophic and disorganization changes, diffuse edema and damage of tissue characteristic for hypoxia effect on the tissues of the adrenal and thyroid glands are noted. Cells, intracellular organelles of both glands have lost their morphological features and are subject to acute destruction. Similar results were obtained in morphometric indicators of the study (Tables 1, 2).

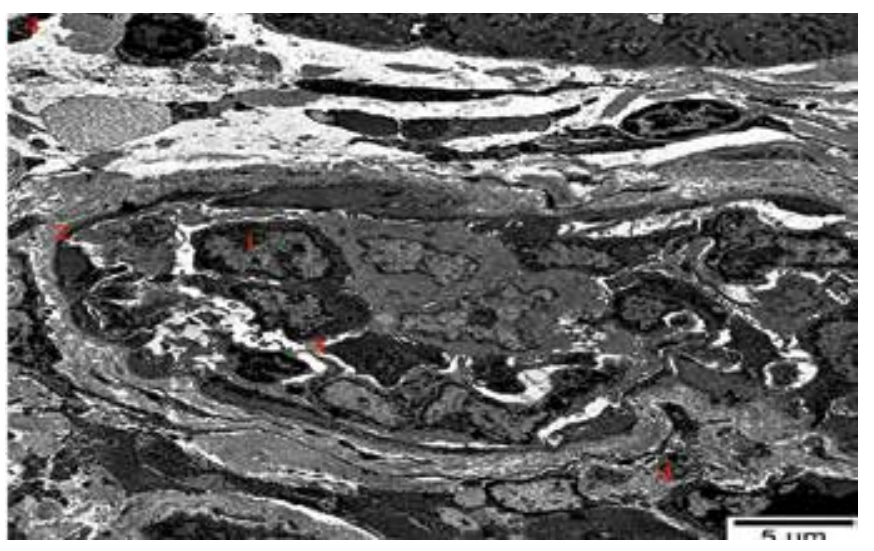

Fig. 4 The $2^{\text {nd }}$ day of hypoxia. Electron micrograph of mitochondria in the cell of the thyroid gland. TEM. Stain: uranium acetate and pure lead citrate. Scale: $5 \mu \mathrm{m} .1$ - thyrocyte; 2 -basal membrane of the follicle-contact portion of the thyrocytes; 3 -complete crystae; 4 looseened plasmolemma 


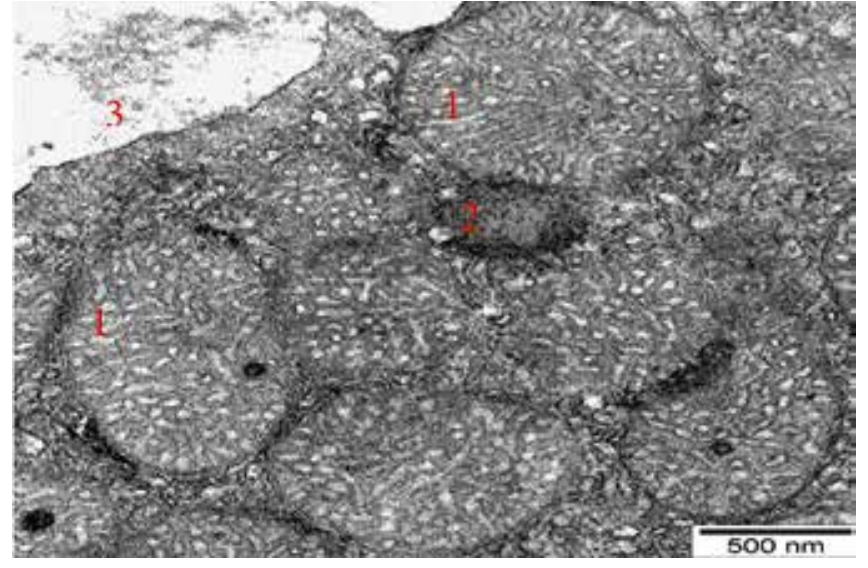

Fig. $55^{\text {th }}$ day of hypoxia. Electron micrograph of structures of the reticular zone of the adrenal gland. TEM. Stain: uranium acetate and pure lead citrate. Scale: $500 \mathrm{~nm} .1$ - lysosome; 2 - destroyed mitochondria; 3 - plasmolemma

Macroscopically, the adrenal and thyroid glands were grayishyellow, sharply increased in volume, softened and became fragile. With the growth of its volume, the connective tissue fibers of capsule covering the glands were loosened, and in some parts, there was an interruption of its integrity, which resulted in the destruction of trabeculae going from the capsule into the gland. The grayish-pink color appearance in the transverse section shows the damage of tissues of the adrenal gland.

On the $5^{\text {th }}$ day of acute hypoxia, most of the cells of the adrenal gland were subjected to degranulation and vacuolization, organelles were subjected to destructive changes, and cytoplasmic proteins were subjected to coagulation and colliquation. In the ultrathin preparations, the cytoplasm and nucleus of adrenocytes are edematous, dark and foamy, and hypertrophied (Fig. 5).

Some cells exhibit, nuclei that have been exposed to karyopiknosis, karyolysis, with nuclear chromatin dispersed and destructed in most cells, mainly in the glomerular zone. In the cytoplasm, a large number of fat droplets are found (Fig. 6). In the cytoplasm, a large number of fat droplets are found, they have arranged under the plasmolemma, almost adjacent to it.

Ultrastructurally, the loosening of mitochondria, the swelling and locally lysis of mitochondrial crystae, vacuolisation of the endoplasmic reticulum and lysosomes are clearly visible. The cisterns of the endoplasmic reticulum are expanded. The absence of lysosomes and ribosomes can be evaluated as a result of acute hypoxia. The intercellular space is expanded, the fibrous structures of the connective tissue are dispersed, the capillaries are plethoric. Ultrastructure of the walls of the capillaries and basal membrane were changed, the completeness integrity of most of them was disrupted. Around some adrenocytes, the local accumulation of cellular elements - neutrophil leukocytes, lymphocytes and histiocytes is clearly visible.

Under the influence of hypoxia, along with karyopyknosis of the nuclei of adrenocytes and the disintegration of chromatin substance, noticeable changes in the number and size of cells, as well as the nuclei are manifested.

The area of cells in all areas of the adrenal cortex, including the adrenal medulla, has increased dramatically compared to the control group. The same dynamics are observed in the area and diameter of the nuclei (Table 1).

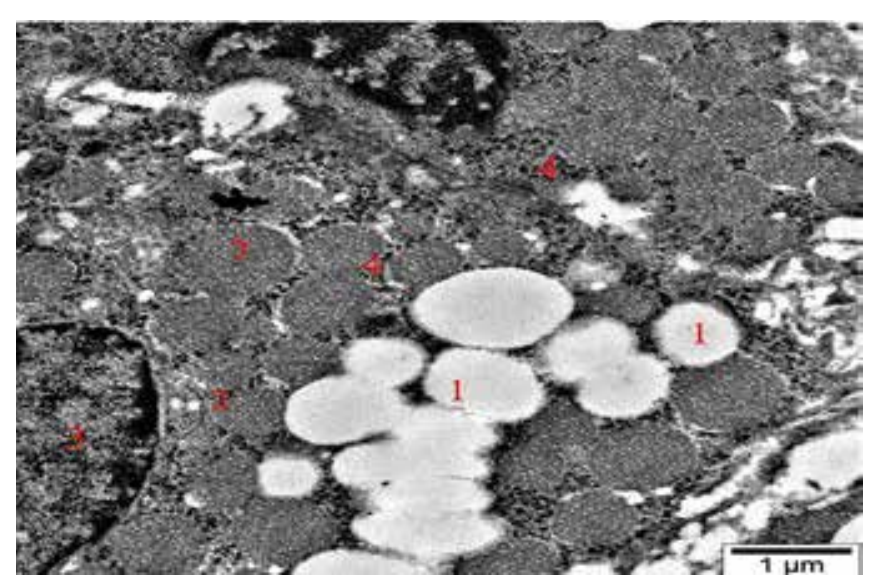

Fig. $65^{\text {th }}$ day of hypoxia. Electron micrograph of structures of the adrenal gland. TEM. Stain: uranium acetate and pure lead citrate. Scale: 1 m .1 -vacuole; 2 -lysosome; 3 -nucleus

On the $5^{\text {th }}$ day of the experiment, under the effect of hypoxia in the ultrathin sections of the thyroid gland, pathological changes in cells - the destruction of thyrocytes and alterations of cytoplasmic organelles attract attention. The layers of the basal membrane of the thyrocytes are swollen and smoothed, thickened and deformed in some parts of the basal membrane. The cytoplasm of cells is edematous, the nuclei are dark, the membrane is not visible, the chromatin is condensed. In some cells, the shrunken nucleus is split into separate particles. Changes in the ultrastructural level in cytoplasmic organelles - complete vacuolization of lysosomes and ribosomes, expansion of the endoplasmic reticulum vesicles, smoothing and swelling of mitochondrial crystae, destruction of the Golgi complex are clearly visible. In the cytoplasm of thyrocytes, especially in the cytoplasm of the peripheral part, it is possible to see the accumulation of numerous large-sized fat droplets, glycogen grains. The interfollicular area is enlarged, edematous, fibrous structures, mainly collagen fibers are dispersed, signs of fibrinoid swelling are noted. The layers of the capillary walls, also have undergone ultrastructural changes (Fig. 7).

Morphometric data obtained as a result of electron microscopic studies have increased compared to the control group. These changes are also clearly visible in the area and diameters of the nuclei (Table 2).

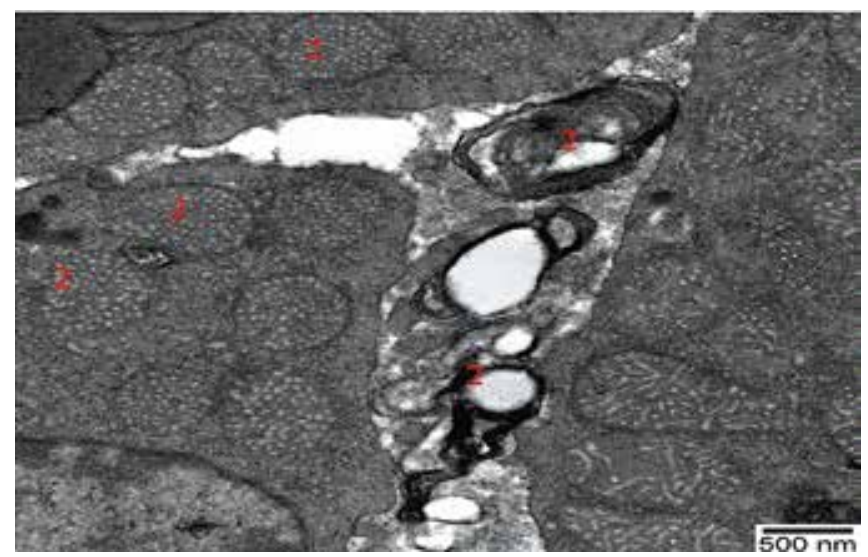

Fig. $75^{\text {th }}$ day of hypoxia. Electron micrograph of the structures of the thyroid gland. TEM. Stain: uranium acetate and pure lead citrate. Scale: $500 \mathrm{~nm}$. 1 -lysosome; 2 -destroyed mitochondria 
As a result of the study, it can be concluded that hypobaric hypoxia affects the structure of the adrenal and thyroid glands as the main "stress» factor, causes cellular and extracellular structural changes in the glands. Because the resistance of the adrenal and thyroid glands to hypoxia, especially strong short-term hypoxic effects, is different, the cells (adrenocytes and thyrocytes), vessels and connective tissue structures of the glands respond with varying degrees of damage and changes with different morphofunctional reactions. It depends on the type of gland tissues or cells, their morphofunctional properties, resistance to hypoxia, the speed of development and duration of oxygen starvation, as well as the intensity of metabolism. Dystrophic and destructive changes in the adrenal gland, compared to the thyroid gland, especially at the ultrastructural level, are more pronounced. These changes, which occur under the influence of hypoxia, are associated with the fatty degeneration of the glandular cells.

The thyroid and adrenal glands play an important role in the adaptation of the body to hypoxia. The morphological effect of experimental hypoxia on the endocrine glands depends on the duration (short-term - acute or long-term - chronic) and degree of hypoxia [18]. Despite the research work devoted to the study of morphofunctional, histological and histopathological changes occurring in the thyroid and adrenal glands during hypobaric hypoxia, the ultrastructural changes occurring in these glands during acute hypoxia have been less studied and the obtained literature data are fragmentary. Therefore, it is difficult to compare the results of our research with those of other researchers.

The adrenal cortex plays an important role in adaptation against the various stress factors, including hypoxia. During acute hypoxia, ultrastructural changes occur in all three zones of the adrenal cortex, and they are accompanied by an increase in the weight of the gland. However, Mohri et al (1983) [19] and Gosney (1985) [20] show an increase in adrenal gland weight on the $14^{\text {th }}$ and $28^{\text {th }}$ days of hypoxia. However, during our studies, an increase in the weight of the adrenal gland is observed in the early stages of hypoxia (starting from the $2^{\text {nd }}$ day). An increase in the weight of the adrenal gland is associated with structural changes in the adrenal cortex (all three zones) and adrenal medulla during acute hypoxia. The diameter and area of the nuclei of both the adrenocytes of the cortical and the medullary substances increases. On the contrary, there is a reduction in gland weight during the later periods of hypoxia (15-30 $0^{\text {th }}$ days). This indicates the adaptation of the gland to new conditions as an adaptive- compensatory reaction. These results are similar to the results obtained by Lorente (2002) [18]

On the $2^{\text {nd }}$ day of the experiment, electron microscopically, weak ultrastructural dystrophic changes in the adrenal cortex and adrenal medulla are detected. These changes are manifested by weak edema, vesicles in the cytoplasm of adrenocytes, the presence of blurred and unclear contours nuclei.

On the $5^{\text {th }}$ day of acute hypoxia, the electron micrographs taken from ultrathin sections show the degranulation and vacuolization of most of the cells of the adrenal gland and the destructive changes in organelles. A large number of fat droplets in the cytoplasm are found.

We would like to note that hypobaric hypoxia is a serious stress factor, causing the ultrastructural changes in the adrenal gland. These changes are more pronounced in the glomerular $[18,21]$ and reticular zones of the adrenal cortex.

Hypobaric hypoxia as the main "stress» factor affects the morphological state of the thyroid gland also and causes the cellular and extracellular ultrastructural changes in the gland. Based on our results, on the $2^{\text {nd }}$ day of the experiment, electron microscopically, weak ultrastructural changes in the follicles of the thyroid gland are detected. These changes are manifested mainly by an increase in the volume of thyrocytes and hypertrophy of intracellular organelles, especially mitochondria.

On the $5^{\text {th }}$ day of the experiment, significant acute dystrophic and disorganization changes, and diffuse edema characteristic of hypoxia in the tissues of the thyroid gland are noted. Because of the destruction of intracellular organelles, the area between the follicles is sharply enlarged, edematous, fibrous structures, mainly collagen fibers are dispersed, and signs of fibrinoid swelling are noted. The layers forming the walls of the capillaries were subjected to ultrastructural changes $[2,20,22,23]$.

Thus, in the comparative analysis of electron micrographs taken from ultrathin sections of both glands, due to acute hypoxia cellular and extracellular acute dystrophic and destructive changes of adrenocyte of the adrenal gland - separation of basal membranes into layers, edema of cells, hypertrophy, and vacuolization of organelles as a compensatory reaction is observed at the early stage of the experiment ( $\left.2^{\text {nd }} d a y\right)$, the same changes are observed on the $5^{\text {th }}$ day of the experiment in thyrocytes and cytoplasmic organelles of the thyroid gland. Early damage of the adrenocytes of the adrenal glands compared to the thyroid gland may be considered as a higher degree of sensitivity of the adrenal gland to hypoxia.

\section{REFERENCES}

1. Akhundov RA. Gipoksiya i antigipoksanty [Hypoxia and antihypoxants]. Baku, Azerbaijan: Aspoligraph; 2010. 328 p.

2. Zarechnova NN, Raytsen VA, Raytsen IV. Morfofunktsional'nye izmeneniya adenogipofiza, nadpochechnikov i podzheludochnoy zhelezy $v$ usloviyakh adaptatsii k vysokogor'yu [Morphofunctional changes of adenohypophysis, adrenal glands and pancreas in the conditions of adaptation to high altitude]. Evraziyskiy soyuz uchyonykh. 2014;6-4:80-1.

3. Berezhanskaya SB, Malinenko Zl. Sostoyanie shchitovidnoy zhelezy u detey rannego vozrasta, perenyosshikh tserebral'nuyu gipoksiyu-ishemiyu [State of the thyroid gland in young children who have undergone cerebral hypoxia-ischemia]. Rossiyskiy vestnik perinatologii i pediatrii. 2011;56(5):51-5.

4. Gridin LA. Sovremennye predstavleniya o fiziologicheskikh i lechebno-profilakticheskikh effektakh deystviya gipoksii i giperkapnii [Modern ideas about physiological and therapeutic and prophylactic effects of hypoxia and hypercapnia]. Meditsina. 2016;4(3):45-68.
5. Kulaeva VV, Bykov VL. Morfometricheskaya i gistokhimicheskaya kharakteristika shchitovidnoy zhelezy pri vozdeystvii peptidnogo morfogena gidry [Morphometric and histochemical characteristics of the thyroid gland under the influence of peptide morphogen Hydra]. Morfologiya. 2016;149(1):64-8.

6. Rumyantseva TA, Krishtop VV, Lencher OS. Kachestvennaya morfofunktsional'naya kharakteristika shchitovidnoy zhelezy krys pri ostroy gipoksii golovnogo mozga $v$ rannie sroki [Qualitative morphofunctional characteristics of the thyroid gland of rats in acute brain hypoxia in early terms]. Krymskiy zhurnal eksperimental'noy $i$ klinicheskoy meditsiny. 2016;6(3):102-6

7. Slynko TN. Morfofunktsional'nye izmeneniya v nadpochechnikakh na pozdnie sroki posle mesyachnogo prebyvaniya v vysokogor'e Kyrgyzstana [Morphofunctional changes in the adrenal glands at a later date after a month's stay in the highlands of Kyrgyzstan]. Evraziyskiy soyuz uchyonykh. 2016;32:15-9. 
8. Shabanov PD, Zarubina IV, Novikov VE, Tsygan VN. Metabolicheskie protektory gipoksii [Metabolic protectors of hypoxia]. Saint Petersburg, RF: Inform-Navigator; 2010. 912 p.

9. Glennon E, Kaunzner UW, Gagnidze K, McEwen BS, Bulloch K. Pituitary dendritic cells communicate immune pathogenic signals. Brain, Behavior and Immunity. 2015;50:232-40.

10. Hermans EJ, Henckens MJ, Joëls M, Fernández G. Dynamic adaptation of large-scale brain networks in response to acute stressors. Trends in Neurosciences. 2014;37(6):304-14.

11. Hueston CM, Deak T. The inflamed axis: the interaction between stress, hormones, and the expression of inflammatory-related genes within key structures comprising the hypothalamic-pituitary-adrenal axis. Physiology \& Behavior. 2014;124:77-91.

12. Hwang GS, Chen CC, Chou JC, Chang LL, Kan SF, Lai WH, et al. Stimulatory effect of intermittent hypoxia on the production of corticosterone by zona fasciculata-reticularis cells in rats. Scientific Reports. 2017;7(1):9035.

13. Lodin-Sundström A, Schagatay E. Spleen contraction during 20 min normobaric hypoxia and 2 min apnea in humans. Aviation, Space and Environmental Medicine. 2010;81(6):545-9.

14. Myers DA, Ducsay CA. Adrenocortical and adipose responses to high-altitude-induced, long-term hypoxia in the ovine fetus. Journal of Pregnancy. 2012;2012:681306.

15. Okur HK, Pelin Z, Yuksel M, Yosunkaya S. Lipid peroxidation and paraoxonase activity in nocturnal cyclic and sustained intermittent hypoxia. Sleep and Breathing. 2013;17(1):365-71
16. Pelin AM, Stefănescu V, Dobre M, Georgescu M. Thyroid structure abnormalities - a prognosis indicator in obese children. Annals of the University Dunarea de Jos of Galati: Fascicle II, Mathematics, Physics, Theoretical Mechanics. 2014;37:159-63.

17. von Wolff M, Nakas CT, Tobler M, Merz TM, Hilty MP, Veldhuis JD, et al. Adrenal, thyroid and gonadal axes are affected at high altitude. Endocr Connect. 2018;7(10):1081-9.

18. Lorente M, Mirapeix RM, Miguel M, Longmei W, Volk D, Cervós-Navarro J. Chronic hypoxia induced ultrastructural changes in the rat adrenal zona glomerulosa. Histol Histopathol. 2002;17:185-90.

19. Mohri M, Set K, Nagase M, Tsunashima K, Jkawakami M. Changes in pituitary-adrenal function under continuous exposure to hypoxia in male rats. Exp Clin Endocrinol. 1983;81:65-70.

20. Gosney JR. Adrenal corticomedullary hyperplasia in hypobaric hypoxia. J Pathol. 1985;146(1):59-64.

21. Chipashvili NM. Changes of adrenal cortex structure in young rats under the single influence of hypobaric hypoxia. Georgian Med News. 2005;123:50-3.

22. Davlatov IA, Gulov MK, Kurbonov S. Morfometricheskaya kharakteristika parametrov komponentov shchitovidnoy zhelezy pri diffuznom toksicheskom zobe [Morphometric parameters characteristic of the components of the thyroid gland at diffuse toxic goiter]. Vestnik Akademii meditsinskikh nauk Tadzhikistana. 2019;9(1):12-7.

23. Slynko TN, Tynalieva BK, Zarechnova NN. Shchitovidnaya zheleza pri deystvii alkogolya posle mesyachnogo prebyvaniya v usloviyakh vysokogor'ya [Thyroid gland under the influence of alcohol after a month's stay in the high altitudes]. Vestnik KRSU. 2017;17(7):194-7.

\section{(i) author information}

Yagubova Samira Mammadhasan, Candidate of Medical Sciences, Associate Professor, Department of Pathological Anatomy, Azerbaijan Medical University

ORCID ID: 0000-0002-6794-7798

E-mail: syagubova.71@gmail.com

Information about the source of support in the form of grants, equipment, and drugs

The author did not receive financial support from manufacturers of medicines and medical equipment

Conflicts of interest: The author has no conflicts of interest

\section{ADDRESS FOR CORRESPONDENCE:}

\section{Yagubova Samira Mammadhasan}

Candidate of Medical Sciences, Associate Professor, Department of Pathological Anatomy, Azerbaijan Medical University

AZ1022, Azerbaijan, Baku, S.Vurgun street, 167, Nasimi

Tel.: +994 (502) 224104

E-mail: syagubova.71@gmail.com

\section{AUTHOR CONTRIBUTIONS}

Conception and design: YaSM

Data collection: YaSM

Statistical analysis: YaSM

Analysis and interpretation: YaSM

Writing the article: YaSM

Critical revision of the article: YaSM

Overall responsibility: YaSM

\section{D СвеДЕНИЯ ОБ АвТОРАХ}

Ягубова Самира Маммадхасан, кандидат медицинских наук, доцент кафедры патологической анатомии, Азербайджанский медицинский университет

ORCID ID: 0000-0002-6794-7798

E-mail: syagubova.71@gmail.com

Информация об источнике поддержки в виде грантов, оборудования, лекарственных препаратов

Финансовой поддержки со стороны компаний-производителей лекарственных препаратов и медицинского оборудования автор не получала

Конфликт интересов: отсутствует

\section{АДРЕС ДЛЯ КОРРЕСПОНДЕНЦИИ:}

\section{Ягубова Самира Маммадхасан}

кандидат медицинских наук, доцент кафедры патологической анатомии, Азербайджанский медицинский университет

AZ1022, Азербайджан, г. Баку, ул. С. Вургун, 167

Тел.: +994 (502) 224104

E-mail: syagubova.71@gmail.com

\section{ВКЛАД АВТОРОВ}

Разработка концепции и дизайна исследования: ЯСМ

Сбор материала: ЯСМ

Статистическая обработка данных: яСМ

Анализ полученных данных: ЯСМ

Подготовка текста: ЯСМ

Редактирование: ЯСМ

Общая ответственность: ЯСМ

$\begin{array}{ll}\text { Поступила } & \text { 05.09.2019 } \\ \text { Принята в печать } & 25.12 .2019\end{array}$

